\title{
Helminth endo-parasites of amphibians from Greame Ama, Okrika, Rivers State, Nigeria
}

\section{Chidinma Charity Amuzie*, Belema Robert, Idorenyin Bassey Ekerette}

Parasitology and Entomology Laboratory, Department of Animal and Environmental Biology, Rivers State University, Port Harcourt, Nigeria

Received: 26 July 2019

Accepted: 30 December 2019

Published online: 31 December 2020

\begin{abstract}
There is only one survey on the species of amphibians and their parasites from Okrika, Rivers State, Nigeria. Therefore, this research was carried out with the intention of exploring the city for more amphibian species and also reporting on the parasites infecting them. Visual acoustic and survey methods were employed in surveying the study location, Greame Ama, for the period of September to November, 2018, and standard parasitological techniques were adopted. In comparison with the earlier research, fewer amphibian species were encountered: Sclerophrys maculata, Hoplobatrachus occipitalis, Ptychadena pumilio and P. mascareniensis. However, new parasite species were found: Diplodiscus fischthalicus, Metahaematoloechus exoterorchis and Cephalochlamys compactus. A higher prevalence of infection (96.6\%) was reported here than in the earlier report. Of the nine parasite species reported in this research, three have direct transmission routes (Rhabdias sp., Cosmocerca ornata, Cylindrotaenia jaegerskioeldii), while six (Raillietiella sp., Cephalochlamys compactus, Mesocoelium monodi, D. fischthalicus, Metahaematoloechus exoterorchis and ascaridida larva) are transmitted by ingestion of either insect or gastropod intermediate hosts. However, the most prevalent species were those with direct transmission routes as is common with more terrestrial amphibian species. It is concluded that amphibian diversity in Okrika is low but more parasite species are likely to be reported with more surveys.
\end{abstract}

Keywords: amphibian diversity, Helminth parasites, Okrika, marine environment

\section{Introduction}

Research into the helminth endo-parasites of amphibians of Okrika, a riverine town in Rivers State, Nigeria, is still very scanty. The only report from this location was the research of Robert et al. (2018). The authors reported very low amphibian diversity comprised of Ptychadena pumilio and $P$. mascareniensis (Ptychadenidae), Sclerophrys maculata (Bufonidae), Silurana tropicalis (Ranidae) and Hoplobatrachus occipitalis (Dicroglossidae) from two communities (Fiberesima Polo and ATC Sandfill) in Okrika. These amphibians played host to few helminth parasites which included Raillietiella sp. (pentastomids), Cylindrotaenia jaegerskioeldii (cestodes), Mesocoelium monodi (trematodes), * Corresponding author: Chidinma Charity Amuzie
e-mail: nmaamuzie@ gmail.com 
Amplicaecum africanum, encysted ascaridida larva, Cosmocerca ornata and Rhabdias africanus (nematodes). These parasites infected $67.4 \%$ of the hosts examined.

In order to fill up the research gap and in an effort to fully report on the amphibian diversity of Rivers State, Nigeria, we undertake the present study at another location in Okrika, namely, Greame Ama. We set off to encounter more amphibian species and to report on the helminth parasites recovered from them.

\section{Materials and methods}

\section{Description of study area}

The amphibians for this study were collected from Greame Ama (Latitude: $4^{\circ} 44^{\prime} 24.00^{\prime \prime} \mathrm{N}$ Longitude: $7^{\circ} 04^{\prime} 58.80^{\prime \prime}$ E) in Okrika Local Government Area of Rivers State, Nigeria. This location lies within the rain forest zone of Rivers State. The rivers in Okrika are marine, so amphibian sampling was restricted to surroundings of homes, moist fields or temporary pools of water found in farms or depressed portions of land, usually after rains, and bush paths and secondary forests.

\section{Sample collection}

The amphibian specimens were collected in the months of September to November, 2018, using the visual acoustic encounter survey (VAES) method. The amphibians were caught by hand-picking from their breeding and feeding sites between the hours of 7p.m and 10p.m, with the aid of powerful flashlights. The specimens were kept in a moistened plastic bucket with perforated lids to keep them alive while they were transported to the Laboratory for proper examination.

The Amphibians collected were identified according to the protocol described by Rodel (2000).

\section{Collection of Parasites}

The amphibians were euthanized by the exposure to chloroform vapor in a killing jar. During dissection, the gastrointestinal tract was divided into oesophagus/stomach, small intestine and large intestine/rectum. The lungs, liver, urinary bladder and body cavity of the specimens were also examined for parasites.

Each section (that is, oesophagus/stomach, small intestine, large intestine, liver, lungs) was placed on a Petri dish containing $0.72 \% \mathrm{NaCl}$. The section was then cut open longitudinally and the solution was properly examined for the presence of parasites. Parasites found were isolated from intestinal and tissue debris and fixed appropriately.

\section{Fixing and quantification of Parasites}

Nematodes were stretched in hot water and preserved in $70 \%$ alcohol. Trematodes and Cestodes were flattened under a cover slip on the microscope slides and fixed in 5\% formol-saline. The fixed specimens were preserved in the same medium (fixative). Nematodes were cleared in lactophenol before examination. Parasites were identified with keys from Prudhoe and Bray (1982) and Riley et al. (1988).

Statistical parasite quantification measures (prevalence and mean intensity) were computed according to Bush et al. (1997).

\section{Results}

A total of twenty-nine specimens were collected over the sample period. They consisted of one toad (Sclerophrys maculata) and three frogs (Hoplobatrachus occipitalis, Ptychadena pumilio and $P$. mascareniensis). The number of each species collected is presented graphically in Fig. 1. 
Chidinma Charity Amuzie et al.

All the specimens were infected, except one $S$. maculata specimen. Thus, the total prevalence of infection was $96.6 \%$. The following parasites were recovered from the infected hosts: Pentastomids (Raillietiella sp.), Cestodes (Cylindrotaenia jaegerskioeldii and Cephalochlamys compactus), Trematodes (Diplodiscus fischthalicus, Metahaematoloechus exoterorchis, and Mesocoelium monodi), Nematodes (Ascaridida larva, Cosmocerca ornata and Rhabdias spp.). As such, there was one pentastomid, two cestodes, three trematodes and three nematodes. The habitat of the parasites within the host is presented in Tab. 1.

From Table 1, it can be noticed that Raillietiella sp. infected only one species, namely, $S$. maculata. The cestodes (or tapeworms), C. jaegerskioeldii and C. compactus, infected one species each, namely, $S$. maculata and $H$. occipitalis, respectively. The trematode, M. monodi, also infected one species, Ptychadena mascareniensis. Diplodiscus fischthalicus and Metahaematoloechus exoterorchis both infected $H$. occipitalis. The nematodes, Ascaridida larva and Rhabdias spp., each infected all the host specimens encountered in this research. Lastly, $C$. ornata infected three species of hosts: $S$. maculata, $P$. pumilio and $P$. mascareniensis. It can also be deduced that $H$. occipitalis was the most infected host species followed by S. maculata, P. pumilio and P. mascareniensis (Fig. 2). The most prevalent parasite species encountered was Rhabdias spp.

Tab. 1. Habitat of parasites in infected amphibians of Greame Ama, Okrika, Rivers State, Nigeria.

\begin{tabular}{|c|c|c|}
\hline Parasite & Host & Habitat \\
\hline \multicolumn{3}{|l|}{ PENTASTOMIDEA } \\
\hline Raillietiella sp. & S. maculata & Lungs \\
\hline \multicolumn{3}{|l|}{ CESTODA } \\
\hline Cylindrotaenia jaegerskioeldii & S. maculata & Small intestine \\
\hline Cephalochlamys compactus & H. occipitalis & Small intestine \\
\hline \multicolumn{3}{|l|}{ TREMATODA } \\
\hline Mesocoelium monodi & P. mascareniensis & Small intestine \\
\hline Diplodiscus fischthalicus & H. occipitalis & Rectum \\
\hline Metahaematoloechus exoterorchis & H. occipitalis & Lungs \\
\hline \multicolumn{3}{|l|}{ NEMATODA } \\
\hline \multirow[t]{4}{*}{ Ascaridida larva } & S. maculata & Body cavity \\
\hline & P. pumilio & Body cavity \\
\hline & H. occipitalis & Body cavity \\
\hline & P. mascareniensis & Body cavity \\
\hline \multirow[t]{3}{*}{ Cosmocerca ornata } & S. maculata & Small intestine \\
\hline & P. pumilio & Small intestine \\
\hline & H. occipitalis & Small intestine \\
\hline \multirow[t]{4}{*}{ Rhabdias sp. } & S. maculata & Lungs \\
\hline & P. pumilio & Lungs \\
\hline & H. occipitalis & Lungs \\
\hline & P. mascareniensis & Lungs \\
\hline
\end{tabular}

The prevalence and mean intensity of parasite infection in the hosts are presented in Table 2. It can be deduced that Raillietiella sp. infected 3.4\% of Sclerophrys maculata examined with six parasites per infected host. Cylindrotaenia jaegerskioeldii infected $7.0 \%$ of $S$. maculata with a mean intensity of about 4 parasites per infected host. On the other hand, Rhabdias spp. infected about $90 \%$ of the $S$. maculata examined at a mean intensity of about 17 parasites per infected hosts.

All three Ptychadena pumilio specimens examined were infected with Cosmocerca ornata, ascaridida larva, and Rhabdias spp. Similarly, the only P. mascareniensis host examined was infected with ascaridida larva, M. monodi and Rhabdias spp. Hoplobatrachus occipitalis was infected with six 
parasite species, D. fischthalicus, M. exoterorchis, C. ornata, Cephalochlamys compactus, Rhabdias spp. and ascaridida larva.

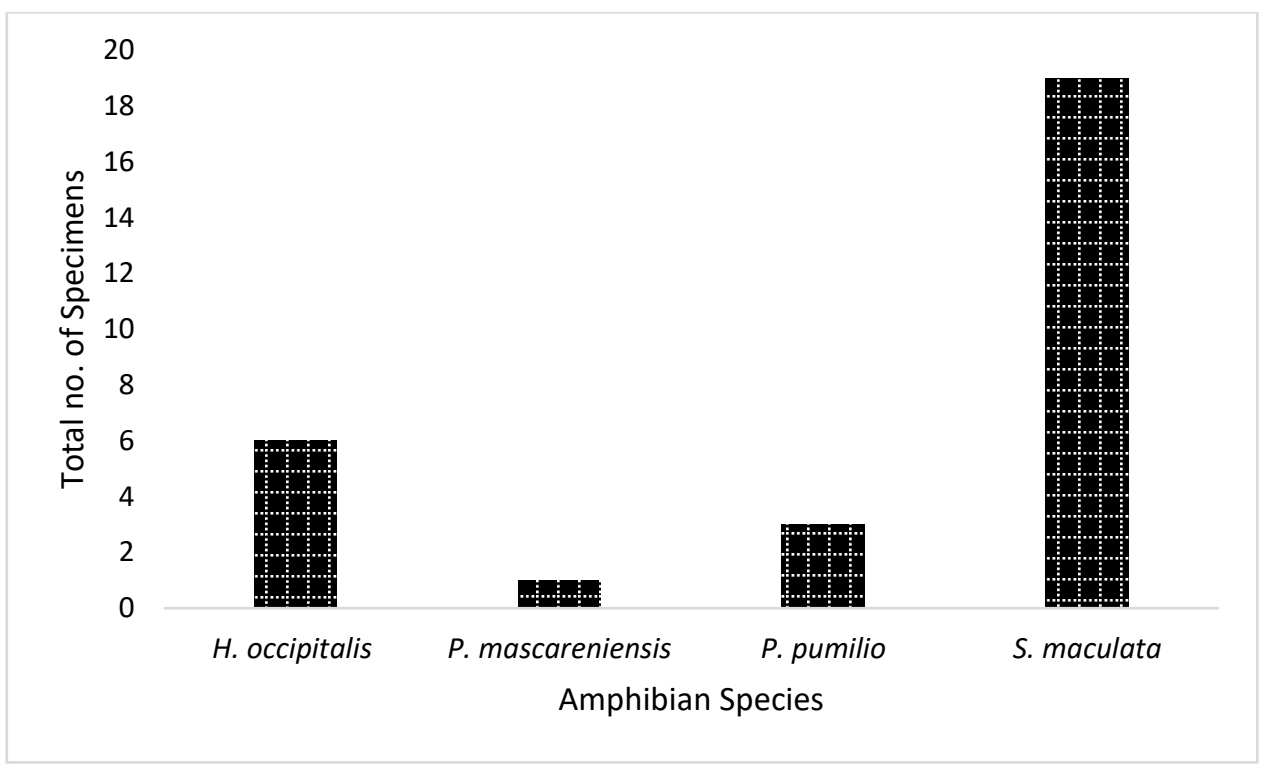

Fig. 1. Number of Amphibian Species collected from the Study Location.

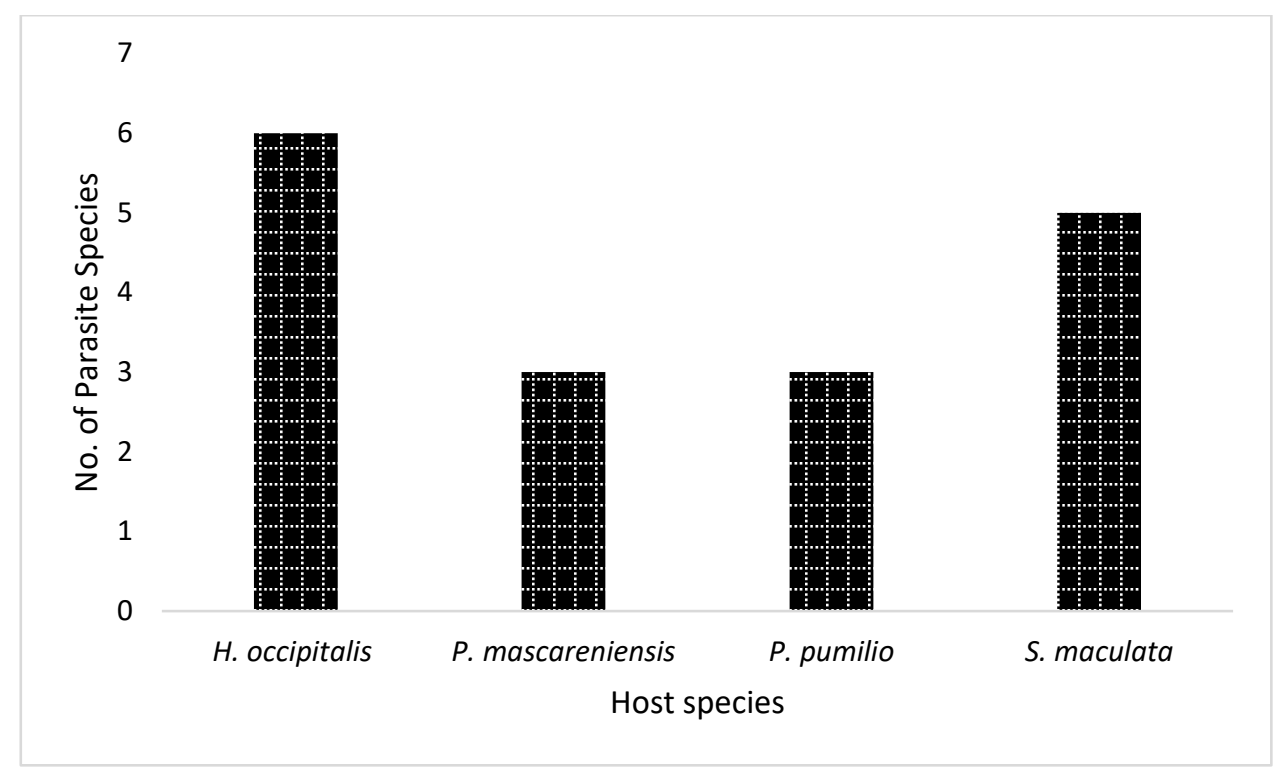

Fig. 2. Number of Parasite Species Recovered from the Host Species Examined during the Study Period.

\section{Discussion}

Four amphibian species were collected from the sample location. The species were, the toad, Sclerophrys maculata, and the frogs, Hoplobatrachus occipitalis, Ptychadena pumilio and $P$. mascareniensis. In an earlier survey in two other locations in Okrika, Robert et al. (2018), found Sclerophrys maculata, Ptychadena pumilio and P. mascareniensis at Fiberesima Polo. At the second location, ATC Sandfill, the authors collected S. maculata, P. pumilio, P. mascareniensis, Silurana tropicalis and Hoplobatrachus occipitalis. These same species were encountered in this research, except S. tropicalis which was not found during the study period. It therefore, follows that the predominant 
Chidinma Charity Amuzie et al.

amphibian species in Okrika, are S. maculata, H. occipitalis, $P$. pumilio and $P$. mascareniensis. However, more survey is needed in order to develop a comprehensive checklist of the amphibian species in the city. The research of Robert et al. (2018) was the first report on the amphibian species and helminth parasite species infecting them at Okrika; this is the second.

The amphibians found in this location are known to be resident in anthropogenically altered environments. They live close to human habitations and around bush clearings, especially $S$. maculata and H. occipitalis (Rodel 2000; Rodel et al. 2008; IUCN 2013, 2016).

Tab. 2. Prevalence and Mean Intensity (MI) of Parasite Infection in Amphibians Species of Greame Ama, Okrika LGA, Rivers State, Nigeria.

\begin{tabular}{|c|c|c|c|}
\hline Parasite & Host & Prevalence (\%) & $\mathrm{MI} \pm \mathrm{SD}$ \\
\hline \multicolumn{4}{|l|}{ PENTASTOMIDEA } \\
\hline $\begin{array}{l}\text { Raillietiella sp. } \\
\text { CESTODA }\end{array}$ & \multicolumn{2}{|c|}{ CESTODA } & $6.0 \pm 0.0$ \\
\hline $\begin{array}{l}\text { Cylindrotaenia } \\
\text { jaegerskioeldii }\end{array}$ & S. maculata & 7.0 & $3.5 \pm 2.1$ \\
\hline $\begin{array}{l}\text { Cephalochlamys } \\
\text { compactus }\end{array}$ & H. occipitalis & 16.7 & $2.0 \pm 0.0$ \\
\hline \multicolumn{4}{|l|}{ TREMATODA } \\
\hline Mesocoelium monodi & P. mascareniensis & 16.7 & $2.0 \pm 0.0$ \\
\hline Diplodiscus fischthalicus & H. occipitalis & 16.7 & $1.0 \pm 0.0$ \\
\hline $\begin{array}{l}\text { Metahaematoloechus } \\
\text { exoterorchis }\end{array}$ & H. occipitalis & 33.3 & $7.0 \pm 1.4$ \\
\hline \multicolumn{4}{|l|}{ NEMATODA } \\
\hline \multirow[t]{4}{*}{ Ascaridida larva } & S. maculata & 73.7 & $4.6 \pm 3.8$ \\
\hline & P. pumilio & 100.0 & $2.0 \pm 1.0$ \\
\hline & H. occipitalis & 66.7 & $4.3 \pm 2.0$ \\
\hline & P. mascareniensis & 100.0 & $3.0 \pm 1.0$ \\
\hline \multirow[t]{3}{*}{ Cosmocerca ornata } & S. maculata & 63.2 & $16.0 \pm 16.0$ \\
\hline & P. pumilio & 100.0 & $10.7 \pm 8.5$ \\
\hline & H. occipitalis & 16.7 & $7.0 \pm 0.0$ \\
\hline \multirow[t]{4}{*}{ Rhabdias sp. } & S. maculata & 89.5 & $16.5 \pm 12.2$ \\
\hline & P. pumilio & 100.0 & $17.7 \pm 5.7$ \\
\hline & H. occipitalis & 50.0 & $5.3 \pm 2.5$ \\
\hline & P. mascareniensis & 100.0 & $13.0 \pm 0.0$ \\
\hline
\end{tabular}

The parasites reported in this project were also similar to those reported by Robert et al. (2018). In this survey, the pentastomid, Raillietiella sp., was recovered along with tapeworms (Cylindrotaenia jaegerskioeldii and Cephalochlamys compactus), trematodes (Mesocoelium monodi, Diplodiscus fischthalicus and Metahaematoloechus exoterorchis), and nematodes (ascaridida larvae, Cosmocerca ornata and Rhabdias spp.). A total prevalence of $96.6 \%$ was reached. In the report of Robert et al. (2018), the total prevalence of infection was 66.67\%. The authors also found pentastomids (Raillietiella sp.), cestodes (Cylindrotaenia jaegerskioeldii), trematodes (M. monodi), and nematodes (Amplicaecum africanum, ascaridida larva, Cosmocerca ornata and Rhabdias africanus). In the present research, new parasite species were encountered which were not reported by Robert et al. (2018). They are as follows: Diplodiscus fischthalicus, Metahaematoloechus exoterorchis and Cephalochlamys compactus.

The most prevalent parasite was the nematode, Rhabdias spp. which is transmitted by direct skin penetration (Shenandoah et al. 2010). This was followed by another nematode, ascaridida larvae, which remain encysted in the body cavity of infected amphibian hosts which serve as its paratenic host (Imasuen et al. 2012). This is in conformity with the research of Hamann and Gonzalez (2015) who 
reported that amphibian species that spend more time in terrestrial than aquatic habitats, such as those encountered in the present research, usually harbor nematode parasites with direct life cycles than trematode parasites which require intermediate hosts.

Nine parasites were encountered in this research with three being directly transmitted into hosts, and six requiring intermediate hosts. Rhabdias spp. and C. ornata penetrate as larva into their hosts (Shenandoah et al. 2010; Kirillova and Kirillov 2015), while Cylindrotaenia sp. is reported to have direct penetration (Ulmer and James 1976). Ascaridida larva is most likely acquired by ingestion of larva-infected insects. The pentastomid, Raillietiella sp. uses coprophagous insects as intermediate hosts (Kelehear et al. 2011; Amuzie et al. 2019); Cephalochlamys compactus likely uses beetles (Imasuen et al. 2012) while the trematodes use snails (Prudhoe and Bray, 1982; Poulin and Cribb, 2002) as intermediate hosts. Though most of the parasite species infecting amphibians of Greame Ama require intermediate hosts, higher parasite burden is accounted for by those with direct life cycles, as is common in terrestrial amphibians (Hamann and Gonzalez, 2015; Amuzie and Wokem, 2018; Amuzie et al., 2019).

\section{Conclusion}

Four amphibian species (Sclerophrys maculata, Hoplobatrachus occipitalis, Ptychadena mascareniensis and P. pumilio) were captured from Greame Ama, Okrika LGA, Rivers State, Nigeria. Sclerophrys maculata was the most abundant but $H$. occipitalis harboured more parasite species. One pentastomid (Raillietiella sp.), two cestodes (Cylindrotaenia jaegerskioeldii and Cephalochlamys compactus), three trematodes (Diplodiscus fischthalicus, Metahaematoloechus exoterorchis and Mesocoelium monodi) and three nematodes (Ascaridida larva, Cosmocerca ornata and Rhabdias spp.) were recovered from these hosts. There was very high prevalence of infection (96.6\%). The host diversity was low but more parasite species are likely to be encountered with surveys of other locations in Okrika.

\section{References}

Amuzie CC, Akani GC, Davies EL (2019) Diversity of helminth parasites in Sclerophrys maculata of Degema and Ogoni, Rivers State, Nigeria. Sokoto Journal of Medical Laboratory Science 4: 43-50.

Amuzie CC, Wokem GN (2018) Survey of helminth parasite species infecting anurans of Azuabie and Woji Communities, Port Harcourt, Rivers State, Nigeria. Sokoto Journal of Medical Laboratory Science 3: $146-155$.

Bush AO, Lafferty KD, Lotz JM, Shostak AW (1997) Parasitology meets ecology on its own terms: Margolis et al. Revisited. Journal of Parasitology 83: 575-583.

Hamann MI, Gonzalez CE (2015) Helminth parasites in the toad Rhinella major (Bufonidae) from Chaco region, Argentina. Acta Herpetologica 10: 93-101.

Imasuen AA, Enabulele EE, Aisien MSO (2012). Helminth community of tree frogs at the Okomu National Park, Edo State, Nigeria. Nigerian Journal of Parasitology 33: 1-8.

IUCN SSC Amphibian Specialist Group (2013) Ptychadena pumilio. The IUCN Red List of Threatened Species 2013: e.T58521A18401115. http://dx.doi.org/10.2305/IUCN.UK.20132.RLTS.T58521A18401115.en. [cited 2019 July 2].

IUCN SSC Amphibian Specialist Group (2016) Ptychadena mascareniensis. The IUCN Red List of Threatened Species 2016: e.T76317565A79825430. http://dx.doi.org/10.2305/IUCN.UK.20161.RLTS.T76317565A79825430.en. [cited 2019 July 2].

Kelehear C, Spratt DM, Dubey S, Brown GP, Shine R (2011) Using combined morphological, allometric and molecular approaches to identify species of the genus Raillietiella (Pentastomida). PLoS ONE 6(9): e24936. https://doi.org/10.1371/journal.pone.0024936.

Kirillova NY, Kirillov AA (2015) Role of the marsh frog tadpoles in the life cycle of Cosmocerca ornata (nematoda: cosmocercidae). Parazitologiia 49: 49-60. 
Chidinma Charity Amuzie et al.

Poulin R, Cribb TH (2002) Trematode life cycles: short is sweet? Trends in Parasitology 18: 176-183.

Prudhoe S, Bray RA (1982) Platyhelminth parasites of the Amphibia. Oxford University Press, London, British Museum (Natural History).

Riley J, McAllister CT, Freed PS (1988) Raillietiella teagueselfi n. sp. (Pentastomida: Cephalobaenida) from the Mediterranean gecko, Hemidactylus turcicus (Sauria: Gekkonidae), in Texas. Journal of Parasitology 74: 481-486.

Robert B, Amuzie CC, Okere SG (2018) Preliminary survey of heminth parasites of amphibians of Fiberesima Polo and ATC Sandfill, Okrika, Rivers State, Nigeria. SF Journal of Environmental and Earth Science 1: 1017.

Rödel MO (2000) Herpetofauna of West Africa, Vol. I. Amphibians of the West African Savanna. Edition Chimaira, Frankfurt, Germany.

Rödel MO, Largen M, Minter L, Howell K, Nussbaum R, Vences M, Baha El Din S (2008) Ptychadena mascareniensis. In: IUCN 2008. 2008 IUCN Red List of Threatened Species. [cited 2019 July 2].

Shenandoah RM, Johnson SA, Haraa AH, McGarrity ME (2010). Preliminary evaluation of the potential of the helminth parasite Rhabdias elegans as a biological control agent for invasive Puerto Rican coquís (Eleutherodactylus coqui) in Hawaii. Biological Control 54: 69-74.

Ulmer MJ, James HA (1976) Studies on the helminth fauna of Iowa II. Cestodes of Amphibians. Proceedings of the Helminthological Society of Washington 43: 191-200. 